\title{
Oxidation Behavior of $\mathrm{SiC}_{\mathrm{f}} / \mathrm{SiC}$ Composites Modified by Layered- $\mathrm{Y}_{2} \mathrm{Si}_{2} \mathrm{O}_{7}$ in Wet Oxygen Environment
}

\author{
WANG Peng ${ }^{1,2}$, WANG Qing-Lei ${ }^{3}$, ZHANG Xiang-Yu ${ }^{1,2}$, YANG Jin-Shan ${ }^{1,2}$, ZHOU Hai-Jun $^{1,2}$, \\ HU Jian-Bao ${ }^{1,2}$, DING Yu-Sheng ${ }^{1,2}$, DONG Shao-Ming ${ }^{1,2}$
}

(1. State Key Laboratory of High Performance Ceramics and Superfine Microstructure, Shanghai Institute of Ceramics, Chinese Academy of Sciences, Shanghai 200050, China; 2. Center of Materials Science and Optoelectronics Engineering, University of Chinese Academy of Sciences, Beijing 100049, China; 3. Beijing Institute of Space Mechanics \& Electricity, Beijing 100076, China)

\begin{abstract}
SiC}_{\mathrm{f}} / \mathrm{SiC}$ composites modified by layered $\mathrm{Y}_{2} \mathrm{Si}_{2} \mathrm{O}_{7}$ were presented in this research. Layered $\mathrm{Y}_{2} \mathrm{Si}_{2} \mathrm{O}_{7}$ was transformed from yttrium oxide by chemical vapor infiltration process in $\mathrm{SiC}$ fiber preform, in which yttrium oxide was generated by the solution impregnation and pyrolysis method. Oxidation behavior of the layered- $\mathrm{Y}_{2} \mathrm{Si}_{2} \mathrm{O}_{7}$ modified $\mathrm{SiC}_{\mathrm{f}} / \mathrm{SiC}$ composites was studied in the wet oxygen environment at $1400{ }^{\circ} \mathrm{C}$, showing that $\mathrm{Y}_{2} \mathrm{Si}_{2} \mathrm{O}_{7}$ can concentrate on the oxidation surface to form a protective layer during the oxidation process. The bending strengths of $\mathrm{SiC}_{\mathrm{f}} / \mathrm{SiC}_{\mathrm{com}-}$ posites with one layer or three layers of $\mathrm{Y}_{2} \mathrm{Si}_{2} \mathrm{O}_{7}$ remain $60.38 \%$ and $71.93 \%$, respectively, after the oxidation for $80 \mathrm{~h}$. In contrast, it is only $50.11 \%$ for $\mathrm{SiC}_{\mathrm{f}} / \mathrm{SiC}_{\mathrm{C}}$ composites without $\mathrm{Y}_{2} \mathrm{Si}_{2} \mathrm{O}_{7}$. Therefore, layered distribution of $\mathrm{Y}_{2} \mathrm{Si}_{2} \mathrm{O}_{7}$ significantly improves the oxidation resistance of $\mathrm{SiC}_{\mathrm{f}} / \mathrm{SiC}$ composites in wet oxygen environment.
\end{abstract}

Key words: ceramic composites; rare-earth silicate; oxidation

$\mathrm{SiC}_{\mathrm{f}} / \mathrm{SiC}$ composites are considered as potential materials for hot-section components in advanced aircraft engine due to their outstanding properties, such as low density, superior toughness, high temperature resistance and non-brittle fracture failure ${ }^{[1-3]}$. However, because $\mathrm{SiC}$ reacts with water vapor and oxygen to form volatile silicon hydroxide $\left(\mathrm{Si}(\mathrm{OH})_{4}\right)^{[4-5]}$, the wet oxygen environment in aircraft engine leads to serious erosion or even failure for $\mathrm{SiC}_{\mathrm{f}} / \mathrm{SiC}$ composites. Environmental barrier coatings (EBCs) were applied on $\mathrm{SiC}_{\mathrm{f}} / \mathrm{SiC}$ composites to overcome the drawbacks as they could isolate the composites from the corrosion and avoid the reaction between $\mathrm{SiC}$ and wet oxygen environment ${ }^{[6-7]}$.

The rare earth silicate $\left(\mathrm{RE}_{2} \mathrm{Si}_{2} \mathrm{O}_{7}, \mathrm{RE}=\mathrm{Y}, \mathrm{Sc}, \mathrm{Yb}, \mathrm{Lu}\right)$ were reported to show low volatilization rate in water vapor environment and the ability to endure temperature higher than $1482{ }^{\circ} \mathrm{C}$ for thousands of hours ${ }^{[8-9]}$. The multi-layer structure EBCs with rare earth silicate as the outermost layer has good corrosion resistance to water vapor and oxygen, which enabled them to be applied to the new generation of advanced aero-engine. Because of the coefficient of thermal expansion (CTE) mismatch ${ }^{[10]}$, the peeling-off of EBCs may occur during the long-term service in aircraft engine and lead to the failure of the composites. Therefore, improving the oxidation resistance of $\mathrm{SiC}$ matrix to water vapor and oxygen is gradually becoming a research hotspot ${ }^{[11-14]} \cdot \mathrm{Y}_{2} \mathrm{Si}_{2} \mathrm{O}_{7}$ has similar CTE with $\mathrm{SiC}\left(\mathrm{SiC}: \sim 4.5 \times 10^{-6} \mathrm{~K}^{-1}, \mathrm{Y}_{2} \mathrm{Si}_{2} \mathrm{O}_{7}: \sim 4 \times 10^{-6} \mathrm{~K}^{-1}\right.$ ) and excellent chemical compatibility with $\mathrm{SiC}^{[15-16]}$. These properties motivate the investigation of $\mathrm{Y}_{2} \mathrm{Si}_{2} \mathrm{O}_{7}$ to modify the $\mathrm{SiC}$ matrix.

The aim of this research is to get a robust matrix with excellent corrosion resistance properties by introducing layered yttrium silicate $\left(\mathrm{Y}_{2} \mathrm{Si}_{2} \mathrm{O}_{7}\right)$ in $\mathrm{SiC}_{\mathrm{f}} / \mathrm{SiC}$ composites. In this study, yttrium oxide $\left(\mathrm{Y}_{2} \mathrm{O}_{3}\right)$ was generated by the solution impregnation and pyrolysis method in $\mathrm{SiC}$ fiber preform firstly, and layered $\mathrm{Y}_{2} \mathrm{Si}_{2} \mathrm{O}_{7}$ was obtained from the transformation of $\mathrm{Y}_{2} \mathrm{O}_{3}$ during chemical vapor infiltration (CVI) process. It is expected that the service reliability of $\mathrm{SiC}_{\mathrm{f}} / \mathrm{SiC}$ composites increases as long as the composites are modified by layered- $\mathrm{Y}_{2} \mathrm{Si}_{2} \mathrm{O}_{7}$.

Received date: 2018-12-17; Modified date: 2019-01-10

Foundation item: National Key Research and Development Program of China (2016YFB0700202); National Natural Science Foundation of China (51772310); Chinese Academy of Sciences Key Research Program of Frontier Sciences (QYZDY-SSWJSC031); Chinese Academy of Sciences Pioneer Hundred Talents Program, Shanghai Pujiang Program (17PJ1410100); Young Elite Scientist Sponsorship Program by China Academy of Space Technology ( 2017QNRC001)

Biography: WANG Peng(1994-), male, candidate of Master degree. E-mail: wangpeng@student.sic.ac.cn

Corresponding author: ZHANG Xiang-Yu, professor. E-mail: xyzhang@mail.sic.ac.cn; YANG Jin-Shan, associate professor. E-mail: jyang@mail.sic.ac.cn 


\section{Experimental}

\subsection{Fabrication of the composites}

2D stitched fabric of silicon carbide fibers (National University of Defense Technology, China) were used as the preforms. BN interphase was deposited by chemical vapor infiltration $(\mathrm{CVI})$. Boron trichloride $\left(\mathrm{BCl}_{3}\right)$ and Ammonia $\left(\mathrm{NH}_{3}\right)(2: 1$, molar ratio) were carried by hydrogen $\left(\mathrm{H}_{2}\right)$ to be deposited at $1073 \mathrm{~K}$ under a total pressure of $3.0 \mathrm{kPa}$. To prevent the erosion of $\mathrm{BN}$ interphase, a thin $\mathrm{SiC}$ layer was also prepared by isothermal CVI at $1000{ }^{\circ} \mathrm{C}$ under a total pressure of $5 \mathrm{kPa}$, in which methyltrichlorosilane (MTS) was used as the precursor of SiC. After the BN interphase and SiC layer were applied on the surface of the fibers, a solution made up of $\mathrm{Y}\left(\mathrm{NO}_{3}\right)_{3} \cdot 6 \mathrm{H}_{2} \mathrm{O}$ (Aladdin, Shanghai, China, 99.99\%) and ethanol was introduced into $\mathrm{SiC}$ preform by vacuum impregnating process. Then the preform was heated to $1000{ }^{\circ} \mathrm{C}$ for $0.5 \mathrm{~h}$ under argon atmosphere and the related preform was named $\mathrm{P}_{1}$. $\mathrm{SiC}$ matrix was then prepared under the same CVI condition as SiC layer. During the process, layered- $\mathrm{Y}_{2} \mathrm{Si}_{2} \mathrm{O}_{7}$ structure could be obtained in $\mathrm{SiC}_{\mathrm{f}} / \mathrm{SiC}$ composites. Solution impregnation pyrolysis process and isothermal CVI were repeated once or three times to obtain the dense composite $\mathrm{C}_{1}$ and $\mathrm{C}_{2}$, respectively, in which one layer or three layers of $\mathrm{Y}_{2} \mathrm{Si}_{2} \mathrm{O}_{7}$ in the matrix could be prepared. A reference sample named $\mathrm{C}_{0}$ was also prepared by the same method but without the solution impregnation pyrolysis.

\subsection{Characterization}

Phase composition of the samples was analyzed using a Micro-region X-ray diffraction (XRD, D8 DISCOVER DAVINCI, Germany). The microstructures of the composites before and after oxidation were characterized using scanning electron microscope (SEM, S-4800, Hitachi, Tokyo, Japan). The elemental analysis was conducted by energy dispersive spectroscopy (EDS, Aztec X-Max 20, Oxford, UK).

The oxidation behavior of the composites was investigated in wet oxygen environment at $1400{ }^{\circ} \mathrm{C}$ with the heating and cooling rates of about $5{ }^{\circ} \mathrm{C} / \mathrm{min}$, and the flow rate of $\mathrm{O}_{2} / \mathrm{H}_{2} \mathrm{O}$ was kept constant at $500 \mathrm{~mL} / \mathrm{min}$ $\left(200 \mathrm{~mL} \mathrm{O}_{2}+300 \mathrm{~mL} \mathrm{H} \mathrm{H}_{2} \mathrm{O}\right)$ by a liquid phase vaporization system (LVD-F1, Hefei Crystal Materials Technology Co., Ltd., Hefei, China). The detail about this system was described elsewhere ${ }^{[17]}$. The density and porosity of the composites were measured by Archimedes drainage method. The bending strength of the composites before and after oxidation were tested by three-point-bending test (DDL20, Changchun Research Institute for Mechanical Science Co. Ltd., Changchun, China) at room temperature and a loading rate of $0.5 \mathrm{~mm} / \mathrm{min}$. The samples were cut and polished to $40 \mathrm{~mm} \times 4 \mathrm{~mm} \times 3 \mathrm{~mm}$, each point was averaged by five samples.

\section{Results and discussion}

\subsection{Chemical composition}

Micro-region X-ray diffraction (XRD) patterns of $\mathrm{C}_{0}$, $C_{1}, C_{2}$ and $P_{1}$ are shown in Fig. 1(a). It can be found that the matrix of sample $\mathrm{C}_{0}$ is mainly made of $\beta$-SiC, which is obtained from the pyrolysis of MTS by CVI. It is shown from sample $\mathrm{P}_{1}$ that $\mathrm{Y}_{2} \mathrm{O}_{3}$ can be formed in the preform after the pyrolysis of $\mathrm{Y}\left(\mathrm{NO}_{3}\right)_{3} \cdot 6 \mathrm{H}_{2} \mathrm{O}$. From the patterns of sample $\mathrm{C}_{1}$ and $\mathrm{C}_{2}, \beta$-SiC and $\mathrm{Y}_{2} \mathrm{Si}_{2} \mathrm{O}_{7}(\mathrm{z}-$ $\mathrm{Y}_{2} \mathrm{Si}_{2} \mathrm{O}_{7}$ : JCPDS Card 21-1459) are found. In order to understand the formation of $\mathrm{Y}_{2} \mathrm{Si}_{2} \mathrm{O}_{7}, \mathrm{XRD}$ of $\mathrm{Y}_{2} \mathrm{O}_{3}$ before and after CVI is carried out (Fig. 1(b)). It shows that $\mathrm{Y}_{2} \mathrm{O}_{3}$ can be transformed into $\mathrm{Y}_{2} \mathrm{Si}_{2} \mathrm{O}_{7}$ completely after CVI. In addition, Energy Disperse Spectroscopy (EDS) of the representative white region in sample $P_{1}$ and $C_{1}$ shows that the atomic ratio of $\mathrm{Y}$ to $\mathrm{O}$ changed from approximately $1: 2$ to $1: 3.5$ (Fig. 2(a-b)), and it can be inferred that $\mathrm{Y}$ exists in the form of $\mathrm{Y}_{2} \mathrm{Si}_{2} \mathrm{O}_{7}$ in sample $\mathrm{C}_{1}$. It demonstrates that the transformation of $\mathrm{Y}_{2} \mathrm{Si}_{2} \mathrm{O}_{7}$ from $\mathrm{Y}_{2} \mathrm{O}_{3}$ with CVI occurs.
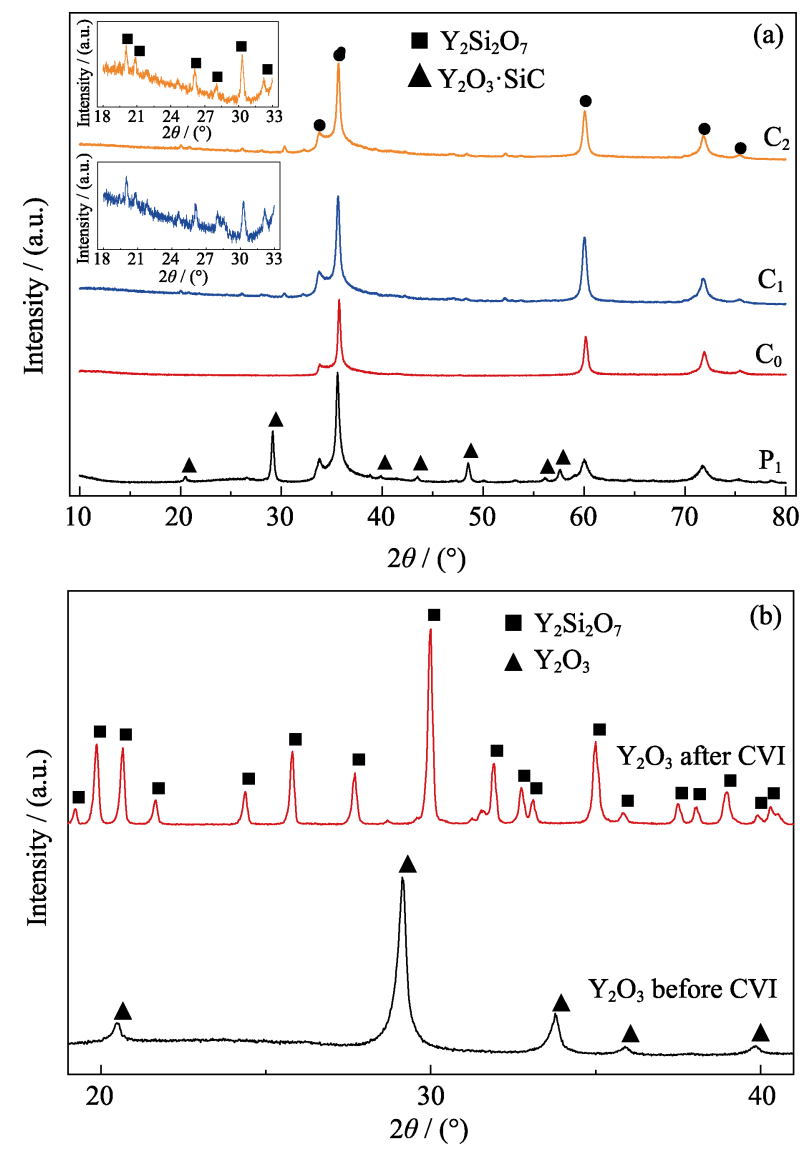

Fig. 1 Micro-region XRD patterns of samples (a) $\mathrm{C}_{0}, \mathrm{C}_{1}, \mathrm{C}_{2}$ and $\mathrm{P}_{1}$, and (b) $\mathrm{Y}_{2} \mathrm{O}_{3}$ before and after CVI 


\subsection{Morphology of the samples surfaces be- fore and after oxidation}

Scanning electron microscope (SEM) images of the polished cutting surface of these composites are shown in Fig. 2. $\mathrm{Y}_{2} \mathrm{Si}_{2} \mathrm{O}_{7}$ with layered distribution can be found around the fiber bundles before oxidation. Sample $\mathrm{C}_{1}$ shows a single-layer distribution (Fig. 3(a)) while sample $\mathrm{C}_{2}$ shows an obvious three-layer distribution (Fig. 3(b)). As it is not dense enough for $\mathrm{Y}_{2} \mathrm{O}_{3}$ after pyrolysis, $\mathrm{SiC}$ can be deposited in the enrichment area of $\mathrm{Y}_{2} \mathrm{Si}_{2} \mathrm{O}_{7}$ due to the inner pores working as the deposition channels. Therefore, the white region is the mixing region of $\mathrm{Y}_{2} \mathrm{Si}_{2} \mathrm{O}_{7}$ and $\mathrm{SiC}$.

Fig. 4 illustrates the oxidation process. The oxidation of $\mathrm{SiC}$ matrix in wet oxygen consists of two parts: oxidation of $\mathrm{SiC}$ by $\mathrm{O}_{2}$ to form silica which is a low viscosity melt in wet oxygen environment, and volatilization of the silica in the form of $\mathrm{Si}(\mathrm{OH})_{4}(\mathrm{~g})$ by reaction with $\mathrm{H}_{2} \mathrm{O}$. Both $\mathrm{SiC}$ and $\mathrm{Y}_{2} \mathrm{Si}_{2} \mathrm{O}_{7}$ exist on the surface before oxidation, and $\mathrm{Y}_{2} \mathrm{Si}_{2} \mathrm{O}_{7}$ remain stable in wet oxygen at high temperature. The volatilization of $\mathrm{Si}(\mathrm{OH})_{4}$ will promote the redistribution of $\mathrm{Y}_{2} \mathrm{Si}_{2} \mathrm{O}_{7}$ in the surface layer of silicate melt during the oxidation process. Therefore, a large amount of dispersed $\mathrm{Y}_{2} \mathrm{Si}_{2} \mathrm{O}_{7}$ can be found on the surface of the composites after oxidation. In sample $\mathrm{C}_{2}, \mathrm{Y}_{2} \mathrm{Si}_{2} \mathrm{O}_{7}$ was more abundant and distributed more widely before the oxidation, so the degree of dispersion is more pronounced and the surface of $\mathrm{Y}_{2} \mathrm{Si}_{2} \mathrm{O}_{7}$ is denser than that of sample $\mathrm{C}_{1}$ after the oxidation (Fig. 3(e-f)). By contrast, for sample $\mathrm{C}_{0}$, the silica glass phase precipitates into crystalline cristobalite in oxidation environment at $1400{ }^{\circ} \mathrm{C}$. Due to the mismatch of the coefficients of thermal expansion $\left(\mathrm{SiO}_{2}\right.$ glass phase: $\sim 7 \times 10^{-7} \mathrm{~K}^{-1}$, crystalline cristobalite: $\sim 170 \times 10^{-7} \mathrm{~K}^{-1}$ ), a large number of cracks on the surface are formed during the cooling process
(Fig. 3(d)), which provide a diffusion channel for oxidizing atmosphere ${ }^{[18]}$.

\subsection{Mechanical properties}

The strength/oxidation time and strength retention rate/oxidation time of the composites are shown in Fig. 5. Before oxidation, the bending strength of $\mathrm{C}_{1}$ and $\mathrm{C}_{2}$ is $(474.93 \pm 24.29) \mathrm{MPa}$ and $(383.61 \pm 30.29) \mathrm{MPa}$, respectively, while sample $\mathrm{C}_{0}$ reaches (532.28 \pm 32.28$) \mathrm{MPa}$. As the impregnation and pyrolysis times increases, the porosity of the composites increase gradually (Table 1) since $\mathrm{Y}_{2} \mathrm{O}_{3}$ can block some pores and hinder the permeation of reactive gases during the CVI process, which may lead to the difference of the mechanical properties. During the oxidation process, $\mathrm{Y}_{2} \mathrm{Si}_{2} \mathrm{O}_{7}$ can disperse on the surface of sample $\mathrm{C}_{1}$ and sample $\mathrm{C}_{2}$ to prevent further diffusion of the oxidizing atmosphere. The mechanical properties of the materials after oxidation are better preserved. After $80 \mathrm{~h}$ of oxidation, the strength retention of sample $\mathrm{C}_{0}, \mathrm{C}_{1}$ and $\mathrm{C}_{2}$ is about $50.11 \%, 60.38 \%$ and $71.93 \%$, respectively.

\section{Conclusion}

Layered $\mathrm{Y}_{2} \mathrm{Si}_{2} \mathrm{O}_{7}$ was prepared to modify $\mathrm{SiC}_{\mathrm{f}} / \mathrm{SiC}$ composites by solution impregnation and pyrolysis combining isothermal CVI process. The result shows that $\mathrm{Y}_{2} \mathrm{O}_{3}$ could be converted into $\mathrm{Y}_{2} \mathrm{Si}_{2} \mathrm{O}_{7}$ by CVI. The oxidation behavior
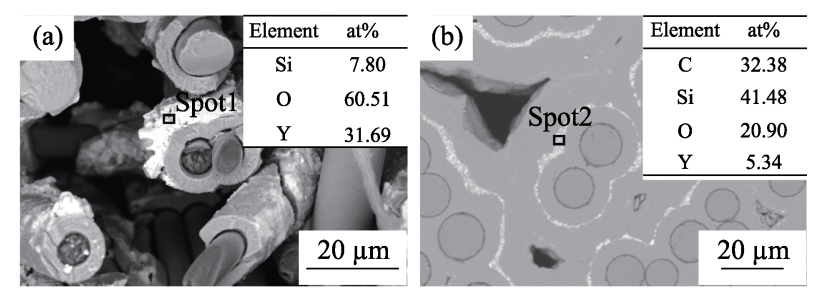

Fig. 2 SEM images of samples (a) $P_{1}$ and (b) $C_{1}$ with insets showing EDS analysis of the white region in sample $\mathrm{P}_{1}$ and $\mathrm{C}_{1}$
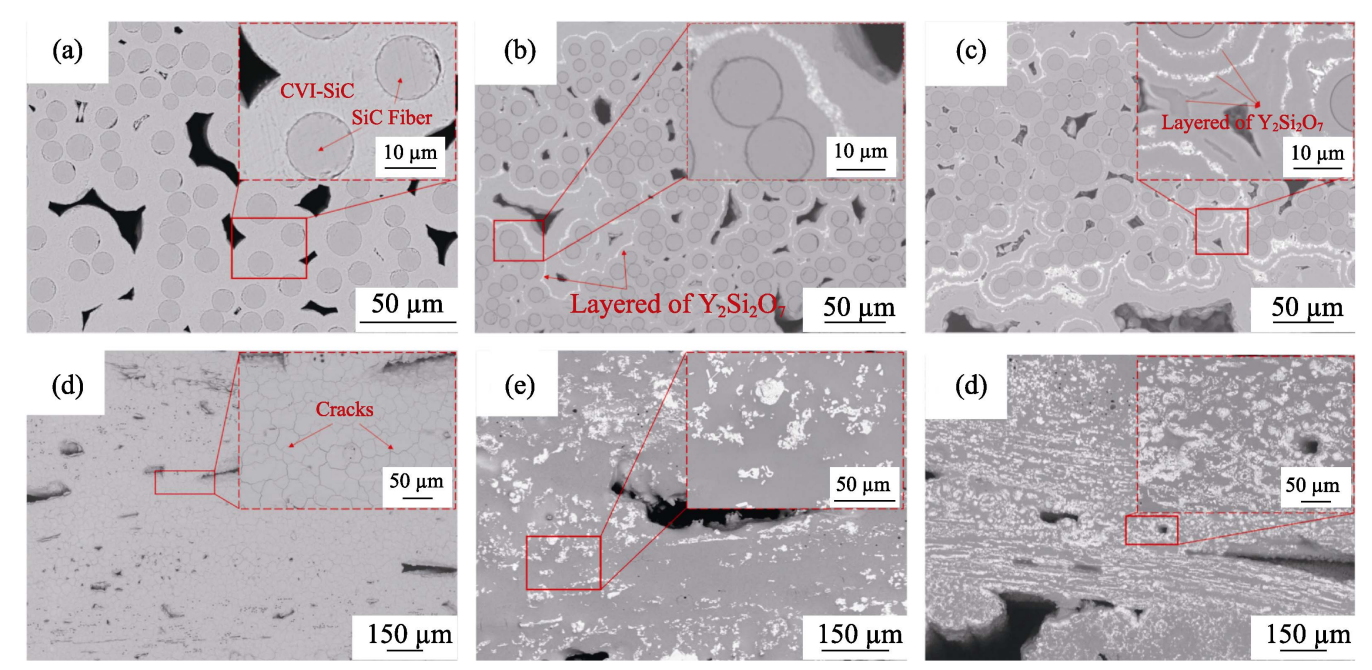

Fig. 3 SEM images of the cutting surface of the composites

Before oxidation: Sample (a) $\mathrm{C}_{0}$, (b) $\mathrm{C}_{1}$, (c) $\mathrm{C}_{2}$. After Oxidation: Sample (d) $\mathrm{C}_{0}$, (e) $\mathrm{C}_{1}$, (f) $\mathrm{C}_{2}$ 


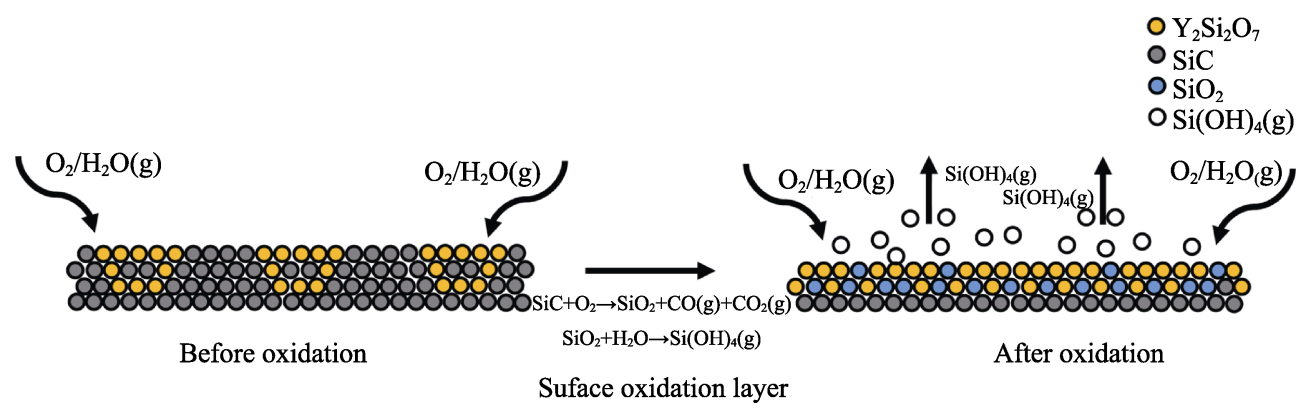

Fig. 4 Oxidation models of $\mathrm{SiC}_{\mathrm{f}} / \mathrm{SiC}-\mathrm{Y}_{2} \mathrm{Si}_{2} \mathrm{O}_{7}$ in wet oxygen
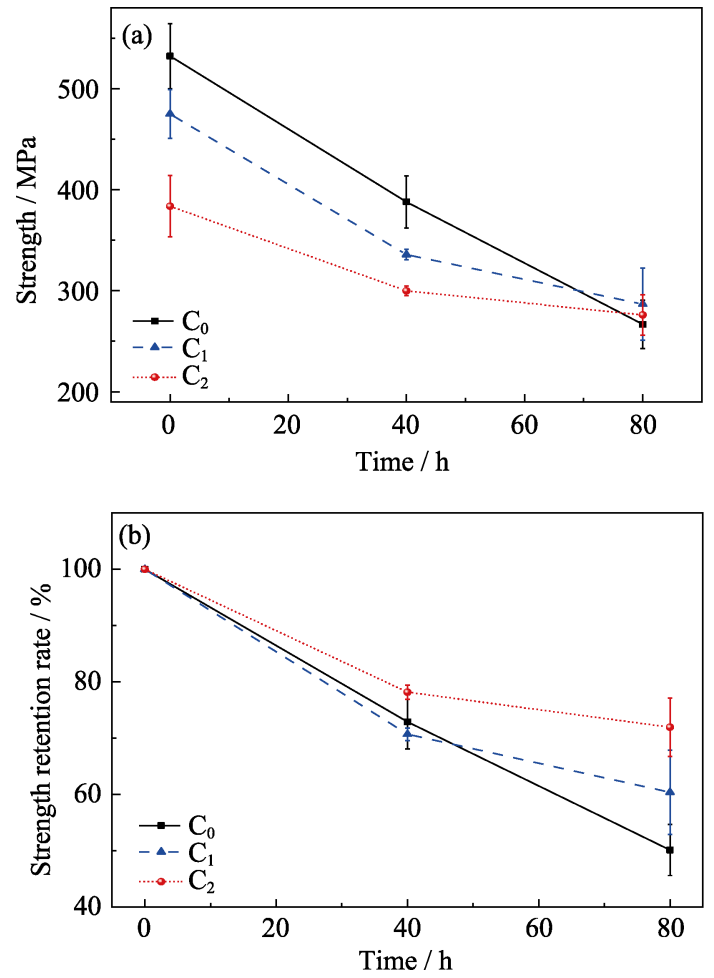

Fig. 5 (a) Mechanical strength and (b) strength retention of the composites after oxidation for different time

Table 1 Density and porosity of the composites

\begin{tabular}{ccrr}
\hline & $\mathrm{C}_{0}$ & \multicolumn{1}{c}{$\mathrm{C}_{1}$} & \multicolumn{1}{c}{$\mathrm{C}_{2}$} \\
\hline Porosity $/ \%$ & $8.69 \pm 0.27$ & $11.49 \pm 0.93$ & $13.63 \pm 0.35$ \\
Density $/\left(\mathrm{g} \cdot \mathrm{cm}^{-3}\right)$ & $2.75 \pm 0.02$ & $2.60 \pm 0.02$ & $2.50 \pm 0.01$ \\
\hline
\end{tabular}

of $\mathrm{SiC}_{\mathrm{f}} / \mathrm{SiC}$ composites modified by layered- $\mathrm{Y}_{2} \mathrm{Si}_{2} \mathrm{O}_{7}$ were tested in the wet oxygen environment at $1400{ }^{\circ} \mathrm{C}$. It demonstrates that $\mathrm{Y}_{2} \mathrm{Si}_{2} \mathrm{O}_{7}$ could form a protective layer over the sample surface and block the oxidizing atmosphere. After the oxidation for $80 \mathrm{~h}$, the retention rate of bending strength of the composite with three layers of $\mathrm{Y}_{2} \mathrm{Si}_{2} \mathrm{O}_{7}$ reaches $71.93 \%$, which is $43.54 \%$ higher than $\mathrm{SiC}_{\mathrm{f}} / \mathrm{SiC}$ without $\mathrm{Y}_{2} \mathrm{Si}_{2} \mathrm{O}_{7}$. It indicates that the addition of rare earth silicate with layered structure could improve the oxidation resistance of $\mathrm{SiC}_{\mathrm{f}} / \mathrm{SiC}$ composites in wet oxygen environment, which has beneficial effect on further application in engine components.

\section{References:}

[1] PADTURE N P. Advanced structural ceramics in aerospace propulsion. Nature Materials, 2016, 15(8): 804-809.

[2] YUAN QIN, SONG YONG-CAI. Research and development of continuous $\mathrm{SiC}$ fibers and $\mathrm{SiC}_{\mathrm{f}} / \mathrm{SiC}$ composities. Journal of Inorganic Materials, 2016, 31(11): 1157-1165.

[3] WANG HONG-DA, ZHOU HAI-JUN, DONG SHAO-MING, et al. Corrosion behavior of $\mathrm{SiC}_{f} / \mathrm{SiC}$ composites in high temperature fluoride salt environment. Journal of Inorganic Materials, 2017, 32(11): 1133-1140.

[4] EATON H E, LINSEY G D. Accelerated oxidation of SiC CMC's by water vapor and protection via environmental barrier coating approach. Journal of the European Ceramic Society, 2002, 22(14/15): 2741-2747.

[5] OPILA E J. Oxidation and volatilization of silica formers in water vapor. Journal of the American Ceramic Society, 2003, 86(8): 1238-1248.

[6] SPITSBERG I, STEIBEL J. Thermal and environmental barrier coatings for $\mathrm{SiC} / \mathrm{SiC} \mathrm{CMCs}$ in aircraft engine applications. International Journal of Applied Ceramic Technology, 2004, 1(4): 291-301.

[7] LIU JIA, ZHANG LI-TONG, HU FEI, et al. Polymer-derived yttrium silicate coatings on $2 \mathrm{D} \mathrm{C/SiC}$ composites. Journal of the European Ceramic Society, 2013, 33(2): 433-439.

[8] XU YUE, HU XUN-XUN, XU FANG-FANG, et al. Rare earth silicate environmental barrier coatings: present status and prospective. Ceramics International, 2017, 43(8): 5847-5855.

[9] WANG YI-GUANG, LIU JIN-LING. First-principles investigation on the corrosion resistance of rare earth disilicates in water vapor. Journal of the European Ceramic Society, 2009, 29(11): 2163-2167.

[10] LEE K N, FOX D S, BANSAL N P. Rare earth silicate environmental barrier coatings for $\mathrm{SiC} / \mathrm{SiC}$ composites and $\mathrm{Si}_{3} \mathrm{~N}_{4}$ ceramics. Journal of the European Ceramic Society, 2005, 25(10): 1705-1715.

[11] LEE S K, READEY M J. Development of a self-forming ytterbium silicate skin on silicon nitride by controlled oxidation. Journal of the American Ceramic Society, 2002, 85(6): 1435-1440.

[12] LI SI-WEI, ZHANG LI-TONG, LIU YONG-SHENG, et al. Self-healing behavior of $2 \mathrm{D} \mathrm{C} / \mathrm{SiC}$ modified by partial boron carbide matrix after annealing at low temperature in wet oxygen. Journal of Inorganic Materials, 2010, 25(11): 1199-1203.

[13] POERSCHKE D L, LEVI C G. Yttrium bearing silicon carbide matrices for robust ceramic composites. Journal of the American Ceramic Society, 2013, 96(4): 1300-1308.

[14] ZHANG QING, ZUO XIN-ZHANG, LIU YONG-SHENG. Oxidation behaviors and mechanisms of CVD Si-B-C ceramic in wet oxygen from $700{ }^{\circ} \mathrm{C}$ to $1400{ }^{\circ} \mathrm{C}$. Journal of the European Ceramic Society, 2016, 36(15): 3709-3715. 
[15] BOAKYE E E, MOGILEVSKY P, PARTHASARATHY T A, et al. Processing and testing of $\mathrm{RE}_{2} \mathrm{Si}_{2} \mathrm{O}_{7}$ fiber-matrix interphases for $\mathrm{SiC}-\mathrm{SiC}$ composites. Journal of the American Ceramic Society, 2016, 99(2): 415-423.

[16] BOAKYE E E, KEY T S, PARTHASARATHY T A, et al. Evaluation of $\mathrm{SiC} / \mathrm{SiC}$ minicomposites with yttrium disilicate fiber coating. Journal of the American Ceramic Society, 2018, 101(1): 91-102.
[17] SHAN QING-LIANG, FENG QIAN, HU JIAN-BAO, et al. Oxidation behavior in wet oxygen environment of $\mathrm{Al}_{2} \mathrm{O}_{3}$ added reaction-sintered Si-B-C ceramics. Ceramics International, 2018, 44(4): 4009-4015.

[18] SHAN QING-LIANG, FENG QIAN, HU JIAN-BAO, et al. MD oxidation behavior in wet oxygen environment of $\mathrm{Al}_{2} \mathrm{O}_{3}$ modified $\mathrm{SiC}_{\mathrm{f}} /\left(\mathrm{SiC}+\mathrm{B}_{4} \mathrm{C}\right)$ at $1200{ }^{\circ} \mathrm{C}$. Materials Letters, 2018, 228: $277-280$.

\title{
层状硅酸钎改性 $\mathrm{SiC}_{\mathrm{f}} / \mathrm{SiC}$ 复合材料湿氧化行为研究
}

\author{
王 鹏 $^{1,2}$, 王庆雷 ${ }^{3}$, 张翔宇 ${ }^{1,2}$, 杨金山 ${ }^{1,2}$, 周海军 ${ }^{1,2}$, \\ 胡建宝 ${ }^{1,2}$, 丁玉生 ${ }^{1,2}$, 董绍明 ${ }^{1,2}$
}

(1. 中国科学院 上海硅酸盐研究所, 高性能陶瓷与超微结构国家重点实验室, 上海 $200050 ; 2$. 中国科学院大学 材料与光电研究中心，北京 100049；3. 北京空间机电研究所，北京 100076)

摘 要: 研究了层状硅酸钇的引入对 $\mathrm{SiC}_{\mathrm{f}} / \mathrm{SiC}$ 复合材料湿氧化行为的影响。首先通过硝酸钇乙醇溶液浸渍热解法向 碳化硅纤维引入 $\mathrm{Y}_{2} \mathrm{O}_{3}$, 再采用化学气相渗透法沉积 $\mathrm{SiC}$ 。层状 $\mathrm{Y}_{2} \mathrm{Si}_{2} \mathrm{O}_{7}$ 主要通过 $\mathrm{Y}_{2} \mathrm{O}_{3}$ 与沉积过程中的 $\mathrm{SiC}$ 反应转 化而成。研究发现, $\mathrm{Y}_{2} \mathrm{Si}_{2} \mathrm{O}_{7}$ 在 $1400{ }^{\circ} \mathrm{C}$ 湿氧环境条件下发生富集, 在氧化层表面形成保护层。氧化 $80 \mathrm{~h}$ 后, 单层和 多层 $\mathrm{Y}_{2} \mathrm{Si}_{2} \mathrm{O}_{7}$ 改性的 $\mathrm{SiC}_{\mathrm{f}} / \mathrm{SiC}$ 复合材料强度保留率分别达到 60.38\%和 71.93\%, 而没有改性的 $\mathrm{SiC}_{\mathrm{f}} / \mathrm{SiC}$ 复合材料强 度保留率仅为 $50.11 \%$ 。结果表明: 层状 $\mathrm{Y}_{2} \mathrm{Si}_{2} \mathrm{O}_{7}$ 的引入可显著提升 $\mathrm{SiC}_{\mathrm{f}} / \mathrm{SiC}$ 复合材料在湿氧环境的抗氧化性能。

关 键 词: 陶瓷基复合材料; 稀土硅酸盐; 氧化

中图分类号: TQ174 文献标识码: A 